\title{
Using Al to Implement O2O Home Health Care Program
}

\author{
Shih-Feng Chang ${ }^{1}$, Wei-Fen Du ${ }^{1}$, Jin Wang ${ }^{1}$, Ma-Yan Lin $^{1}$ and Du Peng ${ }^{1^{*}}$ \\ ${ }^{1}$ Nanfang College of Sun Yat-Sen University, Guangzhou, 510970, China
}

\begin{abstract}
With the continuous growth of China's elderly population, the demand for elderly care services has increased dramatically. Due to the influence of Chinese people's cultural concept of elderly care, most of the elderly are more inclined to home-based care, enjoy the happiness of children and grandchildren, and enjoy family happiness. At present, there are some problems in home-based health care services, such as lack of professional talents and single service mode. This entrepreneurial project which is proposed by Wish Magic has grasped the pain points of China's elderly care problems, and brought about some problems. Efforts should be made to build a sharing platform for elderly care services, attract professionals to provide professional services for the elderly, and hold diversified activities to meet the material and spiritual needs of the elderly. The planned market strategy of the project is divided into three steps. Firstly, the project will be carried out in the first and second tier cities, and then expanded to the third tier cities. Later, the market will be expanded to the fourth tier cities. At the same time, the project will cooperate with government departments to strive for government funding and policy support, and provide accurate services in combination with online and offline ways, so as to meet the diversified pension needs of the elderly.
\end{abstract}

\section{Introduction}

The number of the elderly in China will continue to grow, the pressure of social pension is huge, and the demand of pension service market is large. However, the existing pension institutions and facilities are difficult to meet the demand of pension, the effective supply of pension service is insufficient, the quality and efficiency is not high, and the talent team is also very short.

Therefore, Wish Magic is committed to building a team with professional ability to provide one-to-one intimate health care for the elderly at home, which can make the elderly feel at ease at home, solve the problem of no one to take care of the elderly in double working families, and reduce the pressure of social care. In the next few years, Wish Magic will provide diversified care services elderly service, join the big health strategy and accompany robot service, provide high-quality pension service for the society.

At present, the income of this project which is proposed by Wish Magic is expected to come from the current core product home care service, which will set the relevant price and service content according to the market standards. After that, Wish Magic will hold lectures and arrange physical examination to increase profits. In addition, this project will set up an online shopping mall to sell products for the elderly, which is also an important profit way of this project. Wish Magic will pay more attention to customers to explore the potential needs of the elderly in the service process, and develop products that can solve the needs, through the combination of online and offline sales of products, to meet the potential needs of the elderly and develop our market.

\section{Literature Review}

Due to the short formation time of China's pension industry, there is no real mature model. As an emerging industry involving a wide range, the pension industry needs to be further developed (Guang-Zong Mu, 2000; Guang-Zong Mu, 2012) [3] [4].

According to the white paper on the development of China's pension Industry issued by the Chinese Academy of Social Sciences in 2016, it is estimated that the market of China's pension industry will reach 13 trillion yuan by 2030. Therefore, whether from the perspective of business opportunities or social needs, the pension industry in China should be further developed (De-Hua Zhai and LiQun Tao, 2005) [1].

Otherwise, pension industry has become a new "outlet" for capitalists. There are many market segments of pension industry (Su-Ying Wang, Zuo-Sen Zhang and Wen-Can Sun, 2013; Zhen-Zhen Yang, 2014) [5] [6], including pension real estate, pension finance, pension services and elderly supplies.

According to the statistics of civil affairs in the fourth quarter of 2019, there are 34,065 elderly care institutions in 31 provinces, municipalities and autonomous regions, including 2,527 in Henan Province, 2,415 in Jiangsu Province and 2,401 in Sichuan Province, ranking the first three in China.

By the end of the fourth quarter of 2019 , there are $4,291,712$ beds in pension institutions in China, including

*Corresponding author's e-mail: d92741006@ntu.edu.tw 
426,520 beds in Jiangsu Province, 325,442 beds in Shandong Province and 318,687 beds in Zhejiang Province. The number of beds in pension institutions ranks the top three in China.

From the specific content of elderly care institutions and facilities in the fourth quarter of 2019, we can see that the number of basic elderly care facilities and equipment provided by elderly care institutions can not meet the needs of the current society, and social institutions and other institutions are not fully involved in the elderly care business, so the market demand of silver hair economy is large. Therefore, the market prospect of $\mathrm{O} 2 \mathrm{O}$ home health care project is broad, and there is a lot of development space.

As a matter of fact, as early as a few years ago, Liu Jianping, member of the CPPCC Provincial Committee and vice chairman of Foshan Municipal Committee of the democratic revolution, put forward the proposal of "time bank" for the problem of providing for the aged (Gong Chen and Guo-Gui Huang, 2017) [2].

\section{Research Method}

In view of this, we use case study to explore the way of Wish Magic to do. Compared with other old-age institutions and facilities, Wish Magic can send professional staff to take care of the elderly and provide considerate services. With the consent of their families, it can take the elderly out to play and participate in recreational activities to meet the psychological needs of the elderly. The elderly care is not only to provide them with a comfortable place to spend their twilight years, but also to take care of their parents Soul, enhance their sense of happiness.

The entrepreneurship project is combined with the concept of big health. The project will focus on the elderly's clothing, food, housing, transportation, life, aging and death, pay attention to all kinds of risk factors and misunderstandings affecting health, and also include the investigation of mental, psychological, physiological, social, environmental and moral aspects, so as to provide scientific and healthy life and psychological services for the elderly.

\section{Research Results}

By the end of 2019, there are 253.88 million people aged 60 or above, accounting for $18.1 \%$ of the total population, of which $2.3 \%$ are elderly people aged 80 or above, and about $4 \%$ are disabled or partially disabled.

According to the prediction of "China Development Report 2020: the development trend and policy of China's aging population" issued by China Development Foundation, China will enter the aging society from the aging society around 2022, and the population aged 65 and above will account for more than $14 \%$ of the total population. Therefore, the demand for social pension services is expanding rapidly, and the demand for social pension services is expanding rapidly in the rapidly expanding market of pension institutions.

In addition, according to the specific content of pension institutions and facilities in the fourth quarter of 2019, the number of basic pension facilities and equipment provided by pension institutions can not meet the needs of the current society, and social institutions are not fully involved in the pension business. And with the change of contemporary pension concept, home-based pension model has become a popular pension model in recent years, and this model is in the future At present, there is no mature model of China's pension market, and the home-based pension market needs to be further developed.

In the first half of 2019, there are more than 80 listed companies of pension enterprises, most of which belong to the real estate industry, accounting for 39\%. Large listed real estate enterprises such as Vanke, poly, COSCO and Fosun also pay attention to the pension market to develop their pension business. Some of them expand their business to financial insurance, trying to carry out the operation mode of "insurance + pension". These enterprises include large insurance companies such as Hezhong life insurance and Shoukang insurance (see Table 1).

In view of this, the value proposition of $\mathrm{O} 2 \mathrm{O}$ home health care project launched by Wish Magic is to provide professional home care services, take care of the elderly, and solve the needs of companionship and health for the elderly, and to provide health care services for the elderly at home by combining the new mode of "Internet + pension + artificial intelligence" with online platform + offline institutions.

The project mainly provides home health care for customers. Firstly, the online platform can be used to make an appointment for physical examination and purchase drugs. Secondly, the offline organizations can hold a variety of entertainment activities for the elderly, including tourism, tea party, drama meeting and family gathering for the elderly, so as to meet the basic needs of the elderly and their needs for a better life.

The innovation of the project is to adopt the "shared employees" mode, maximize the self use, provide customers with flexible, efficient and reassuring health care services for the elderly, solve the problem of two employee family pension, and reduce the social pension pressure in China.

In addition, the project cooperates with colleges and universities to recruit and train talents matching with enterprises, so as to train talents for the project and transport suitable talents to other pension enterprises at the same time. 
Table 1. Three main layout of pension industry.

\begin{tabular}{|c|c|c|c|}
\hline Type & $\begin{array}{l}\text { Reasons for Entering the } \\
\text { Field of Pension }\end{array}$ & Core Concerns & Inferiority \\
\hline $\begin{array}{c}\text { Pension Service } \\
\text { Operation Company }\end{array}$ & $\begin{array}{l}\text { Seeking Professional } \\
\text { Development of Silver } \\
\text { Hair Market }\end{array}$ & $\begin{array}{l}\text { Operation } \\
\text { Oriented }\end{array}$ & $\begin{array}{l}\text { It is difficult to expand rapidly due to the } \\
\text { long cycle of capital return and the relative } \\
\text { weakness of its own strength. }\end{array}$ \\
\hline $\begin{array}{c}\text { Real Estate } \\
\text { Development Company }\end{array}$ & $\begin{array}{l}\text { Implementing Diversified } \\
\text { Strategy and Seizing the } \\
\text { Blue Ocean of Pension } \\
\text { Real Estate }\end{array}$ & $\begin{array}{l}\text { Development } \\
\text { Oriented }\end{array}$ & $\begin{array}{l}\text { The investment return cycle of pension } \\
\text { project development is long, which is } \\
\text { contrary to the fast turnover mode of } \\
\text { housing. }\end{array}$ \\
\hline Insurance Company & $\begin{array}{l}\text { Grasp Huge Insurance } \\
\text { Funds and Seek } \\
\text { Investment Channels with } \\
\text { Stable Rate of ROI } \\
\end{array}$ & $\begin{array}{l}\text { Investment } \\
\text { Oriented }\end{array}$ & $\begin{array}{l}\text { Subject to the regulatory system of CIRC, } \\
\text { investment in pension real estate can only be } \\
\text { held, not sold, affecting the return of funds. }\end{array}$ \\
\hline
\end{tabular}

\section{Conclusions and Suggestions}

In order to cope with the aging population, the Chinese government, based on its national conditions, has formulated the policy of "home-based, community-based, institution based, and medical care combined".

In recent years, a series of pension related policies have been issued to promote and support the reform and development of community pension model, deepen the combination of medical care and pension, promote smart pension and open pension financial market.

With the rapid expansion of the demand for social pension services, the government needs to set a "scale" as a unified evaluation standard in the large expansion of the pension institution market. At present, the State Administration of Market Supervision and the National Standardization Management Committee have issued the "grading and evaluation of elderly care institutions", which will force social elderly care institutions to upgrade their production capacity as soon as possible.

On September 9, 2019, the National Development and Reform Commission (NDRC) released the implementation plan of the special action of the city enterprise linkage for the inclusive elderly, which requires the comprehensive use of various policy advantages to formulate the implementation plan of the pension service board combination financing, such as the exemption of value-added tax for community pension service institutions, the linkage of price and CPI, and the subsidy ceiling of 100-200 million yuan.

The data shows that the proportion of the tertiary industry in GDP has increased year after year, from 50.8\% in 2015 to $53.9 \%$ in 2019 . The rapid growth of the tertiary industry indicates that China's pension service industry will have a broader prospect, and other secondary industries related to pension industry will also have a lot of development space.

However, the level of economic development and population density are different, so there are some differences in the development of the corresponding pension market. From a regional perspective, North China, East China and Southwest China are the leading regions in the development of China's pension market. The overall market size occupies the leading position in the country, with market shares of $18 \%, 25 \%$ and $17 \%$ respectively.
Among them, East China is the leading region in the development of China's pension market.

According to the preliminary calculation of China's GDP in the third quarter of 2020, the main results show that China's economic development trend is good. In the face of the huge impact of Covid19 and the complex and severe domestic and international environment, all regions and departments have scientifically coordinated the epidemic prevention and control and economic and social development, and effectively promoted the recovery of production and life order. In the first three quarters, the economic growth has turned from negative to positive, the relationship between supply and demand has gradually improved, the market vitality has been enhanced, employment and people's livelihood have been better guaranteed, and the national economy has continued to recover stably, The overall social situation remained stable

Besides, the added value of the tertiary industry was 40039.7 billion yuan, an increase of $0.4 \%$. On a month on month basis, GDP grew by $2.7 \%$ in the third quarter. The service industry has recovered steadily, and the growth of modern service industry is good. The home health care project belongs to the service industry, which has a positive impact on the current economic situation in China. The country's economic development shows an upward trend, and the market has strong vitality, which is conducive to the long-term stable development of the pension service industry.

As the number of the elderly in China will continue to grow, the pressure of social pension is huge, so the demand of pension service market is large. However, the existing pension institutions and facilities are difficult to meet the demand of pension, the effective supply of pension service is insufficient, the quality and efficiency is not high, and the talent team is short.

Therefore, Wish Magic is committed to building a team with professional ability to provide one-to-one intimate health care for the elderly at home, which can make the elderly at home, solve the problem of no one to take care of the elderly in double working families, and reduce the pressure of social support. In the next few years, Wish Magic will provide diversified elderly care services and join the big health war As well as accompanying robot services, providing high-quality pension services for the society.

Otherwise, Wish Magic can also help the country 
reduce the burden of providing for the aged, and provide more comprehensive and professional quality services for the elderly. In addition, Wish Magic will cooperate with major universities to help other companies find and cultivate high-quality talents besides solving the employment problems of fresh graduates.

\section{References}

1. De-Hua Zhai, Li-Qun Tao (2005) Theoretical research on decision model of home care and institutional care. Market and Population Analysis, S1: $62-64+38$.

2. Gong Chen, Guo-Gui Huang (2017) Local development, practice and innovation of time bank - also on the new ideas of actively coping with China's aging population. Beijing University Journal of Philosophy and Social Sciences, 54(6): $112-120$

3. Guang-Zong $\mathrm{Mu}$ (2000) Reform and prospect of Chinese traditional pension mode. Journal of Renmin University of China, 5: 39-44.

4. Guang-Zong $\mathrm{Mu}$ (2012) The dilemma and countermeasures of the development of institutional pension in China. Journal of Central China Normal University (Humanities and Social Sciences), 2: 31-38.

5. Su-Ying Wang, Zuo-Sen Zhang, Wen-Can Sun (2013) The mode and path of the combination of medical care and pension: an investigation report on promoting the combination of medical care and pension services. Social Welfare, 12: 11-14.

6. Zhen-Zhen Yang (2014) Construction and empirical research on the financing mode of social pension service combining medical care and pension. Doctoral Dissertation of School of Public Administration of Zhejiang University. 